\title{
Potential of ICT in Teaching English as a Foreign Language Focused on Autistic Spectrum Learners
}

\author{
Beáta Jelínková ${ }^{*}$ \\ ${ }^{1}$ Constantine the Philosopher University, Trieda Andreja Hlinku 1, 94974 Nitra-Chrenová, \\ Slovakia
}

\begin{abstract}
The number of children with Autistic Spectrum Disorders (ASDs) educated under mainstream school system is still raising. Since English is a compulsory subject for every school child in Slovakia, students with ASDs also belong to the group of English language learners. Thereupon causing worries to teachers and calling for a necessity of a wider concept. The purpose of the study is to help the ASDs learners and their teachers to acquire the curriculum under the virtue of ICT. Data were collected via the Case Study as the main research, based on teacher's daily experience in teaching English to ASDs children. Results are presented in the form tables and figures and prove the expectation to meet special educational needs of ASDs.
\end{abstract}

\section{Introduction}

Many people may think that a person suffering from autism is "Rain Man", the movie character created by Barry Morrow in 1998. The man, who is unable to live common life, not able to walk across the street and has a problem to communicate. The person, who lives his own imaginary life, loves stereotypes and rules because they give him security. However, this is not merely only a character as teachers nowadays frequently meet. Some children behave unusually and strangely. Teachers are often curious, how it is possible that a child being so clever, can be so immature. The research made by Starcic (2014) concluded that the diagnosis of autism in the mainstream education might be more common than it might seem. The inclusion level of the children with learning disabilities into mainstream schools in the United Kingdom was $28.81 \%$ in 2014, with the growing tendency. In comparison to Slovakia, according to official statistics of Ministry of the Education, Science, Research and Sport of the Slovak Republic, there are about $10 \%$ of special education needs children at primary schools in the country, whist the Centers of Specialized Pedagogical Counselling provide the help to more than 88,000 children. The higher prevalence of SEN is strongly influenced by better diagnostics, as teachers are more educated on this issue and able to recognize the symptoms of learning disabilities.

One of the diagnoses included under special educational needs learners (SEN) is also autistic spectrum disorder students (ASD), and the occurrence of Autistic spectrum disorders is $1 \%$, with the prevalence of male to female (Baron - Cohen, 1998). The reason could lie in improved diagnostic tools. Teachers are also more experienced in recognition of the symptoms on autistic spectrum disorders. Equally important is the fact that parents are more informed on the issue and look for professional advice themselves, however, they are able to

* Corresponding author: beata.jelinkova@ukf.sk 
receive only psychological help as factors responsible for autism are still the matter of scientific research and thus there are not any remedies on the autism yet.

Since English is a compulsory subject for every school child in Slovakia, students with special educational needs also belong to the group of English language learners who are coming into foreign language classes. For that reason, English teachers at primary schools face the demanding job of meeting needs of all types of learners including those with diagnosed learning needs.

The specialists in pedagogy Seidler and Kurincová (2011) analyses the current state, conditions and aspects of the inclusion and teaching special education needs learners in Slovakia at primary schools as following:

1. The parent's involvement in education process of special educational needs students is vital.

2. Those students without the parents' support make a little progress.

3. Without special pedagogist, SEN students are lost in mainstream primary schools.

4. Teachers call for the necessity of more materials and help in the process of inclusion.

As the above-mentioned authors claim, the special educational needs learners, especially children having high functioning autism or Asperger's syndrome need more professional help, and more of parents' involvement in their education.

\section{Didactics of foreign language teaching for SEN learners}

To learn a foreign language, one must master certain components like memory abilities, phonetic coding ability, grammatical sensitivity, and inductive learning ability. Students must meet a set of requirements, goals, and competencies when acquiring a foreign language. The education of students with Autistic spectrum disorders is carried out in accordance with the current legislation of Ministry of Education and recommendation guideline of State educational program of the Slovak Republic. The similarly is applicable also in the Czech Republic. As the guideline fully specifies, teachers need professional advice from psychologists who prepare the tailored individualized educational programme as well as provide recommendations on teaching and compensational aids the children having some special needs or pervasive disorders (Kendal, 2009). An Individualized Educational Program in particular, helps both students and teachers to work according to the skills because the program is developed with the consideration of the specific needs of the student (Zelinková, 2009).

Kormos and Smith (2012) provide the detailed professional advice on teaching foreign language to special educational needs learners who face a lot of problems while learning a foreign language in comparison to their peers without impairments and summarise their recommendations on teaching principles of English as a foreign language to in gaining learning skills, namely listening, reading, writing, speaking, also grammar and vocabulary.

Among one of the biggest contributions to teaching English as a foreign language to learners with learning disabilities and autism in Slovakia was made by Homolová ( 2013). From the given monographs, we chose advice on teaching vocabulary and grammar because they are the most frequently tested in challenging for SEN learners.

Vocabulary - should create the base in the foreign language learning because SEN learners have to meet the requests on vocabulary specified in State Educational program for a particular year. The revision is essential in gaining a new vocabulary and learners tend to forget the most within one day of learning. It is especially true for SEN learners, who have weakened long-term memory. Visualization of a new vocabulary in the form of pictures is also beneficial for SEN learners. The translation is suitable for ASD students; however, dyslexic children should also use acoustic and tactile memory in gaining vocabulary. 
Grammar - the grammatical categories, particularly tenses, word orders and simple negation are the most challenging for SEN learners. The long explanations of rules do not help those type of learners and therefore, the simple rule, especially visualised form is helpful. For instance, SEN learners can use the cards with the summary or example of tenses, creation of negative, affirmative sentence and questions because that type of cards help the SEN learners to remember and they fulfil the request for visualization.

In Slovakia Homolová (2013) in her monograph recommended the most suitable types of exercises for autistic spectrum learners of foreign language teaching as followed:

- matching exercises; multiple choice; dragging - antonyms, synonyms; spot the differences; word orders; cloze exercises; mind maps; match the picture to the definition; categorization; Yes / No questions; crosswords; tick the correct picture; listen and do and choose and fill in. Our research focuses on the suitability of online grammar exercises for SEN learners of English language and thus we plan to examine them in practical part.

In addition to above mentioned, Mark Hutten, counselling psychologist provides researched-based strategies on teaching Autistic Spectrum children as following:

- Visual and auditory stimulation in the classroom ought to be taken into consideration because Autistic Spectrum Disorders students are sensitive to auditory input and have a more difficult time processing auditory stimulation.

- ASD students perform the best when their daily routine is predictable since they are not flexible. Visual schedules help the ASD students to be prepared for the transitions. The schedule must be visual and kept in the same location at all time.

- Activities should be designed with the strong visual cues so less auditory directions are needed.

- Many ASD students have impairments in communication, particularly expressive communication. It is common for students to be unable to access verbal communication when in a stressful emotional state. Having a back-up visual form of communication can assist with expression and reduce aggressive behavior.

- The daily program needs to be implemented as consistently as possible (parentingautisticchild.com).

Besides above mentioned, Kendal (2009) gives a deep view on teacher's checklist activities during the lessons. We chose the checking questions that seem us the most useful in preparing the lesson plan.

1. Are your activities engaging and motivating for Autistic Spectrum students?

2. Are your objectives, routines and rules clearly understood?

3. Do you demonstrate respect for the ASD students?

4. Do you ensure you have the student's attention before starting?

5. Do you have a variety of awards and consequences that are well known by ASD students?

6. Do you pause when ASD students interrupt?

The same author (ibid) also advises how to teach ASD students.

- Teachers should make sure that their classes and instructions are truly clear and concrete.

- Use many different methods of explaining something: visual, written, spoken, and demonstrated.

- Hands-on activities to explain a concept can work very well.

- Be prepared to explain a concept many time. 
- Know that ASD students are mostly visual learners.

One of the possible solutions how to teach students having High functioning autism lies in the use of ICT.

\section{The participants characteristics}

Students suffering from Asperger's syndrome and High functioning autism have problems in establishing social links, have pedantic and repetitive speech, difficulties in managing conversations, resistance towards changes in daily routine and low attention span (Zelinková, 2009). The results of study made by specialists in autism (Mattila, 2010) present that Autistic spectrum disorder students suffer from the higher occurrence of comorbid psychiatric disorders, such as depression, anxiety, and Tourette syndrome. These students have difficulty with problem solving, especially with audio information processing that is caused by the weakened short-term memory that affects the ability to follow instructions, namely in the disturbing environment that school is. Autistic spectrum students can also have the various learning disorders, mainly attention deficit disorders causing the need for class accommodation in the form of special education needs. As stated by Carrol (1990, p.14), the results of the research on the component of foreign language aptitude have been without great changes since 1959 and they include following aspects:

- grammatical sensitivity

- phonetic coding ability

- memory abilities

- inductive language learning ability

- auditory ability.

By the same token, students suffering from Asperger's syndrome and High functioning autism have problems in establishing social links, they have pedantic and repetitive speech, difficulties in managing conversations, resistance towards changes in daily routine and low attention span. It was proved that Autistic spectrum disorders students have relatively intact visuospatial abilities, good auditory short-term and memory skills as well as remarkable visual memory.

Table 1: Research sample.

\begin{tabular}{|l|l|l|l|}
\hline Participant & Age & Diagnoses & $\begin{array}{l}\text { Recommendations from psychologists on } \\
\text { tests }\end{array}$ \\
\hline A boy & 12 & Asperger syndrome & $\begin{array}{l}\text { Short test with Yes/No answer, multiply } \\
\text { choice, prolonged time for testing, in his bad } \\
\text { days to prefer oral exams, prolonged time for } \\
\text { testing }\end{array}$ \\
\hline
\end{tabular}

Our research sample is created by a boy, aged 12, diagnosed with Asperger syndrome. We searched for psychologist's recommendations on testing knowledge English as a foreign language to a participant. As the table shows, the testing tasks ought to include Yes/No answer, multiply choice. Furthermore, the participant needs prolonged time for testing to avoid stress.

\section{Research method}

This research is aimed at analysing attitudes to gain grammar and vocabulary of Autistic Spectrum Disorder students via the virtue of Information and Communication Technology 
(ICT). As the main research method, we used the Case study. As a tool of our research we used the online practice available from Project textbook by Oxford University Press that has been used to teach English in most Slovak schools for over two decades. Didactic tests of online practice were used to evaluate learners' knowledge, focused on grammar and vocabulary. As the Table 2 and Table 3 show, Didactic tests comprise of various kinds of grammar and vocabulary exercises as following:

1. multiple choice

2. matching

3. open questions

4.words order

5. find the mistake

Table 2: Results of grammar and vocabulary exercises.

\begin{tabular}{|c|c|c|c|c|c|c|}
\hline & 01 & 02 & 03 & 04 & 05 & Lesson Total \\
\hline Grammar & $\underline{\text { View }}$ & View & $\underline{\text { View }}$ & View & $\underline{\text { View }}$ & \\
\hline Attempts & 1 of 3 & 1 of 3 & 1 of 3 & 1 of 3 & 1 of 3 & 5 \\
\hline Score & $\begin{array}{l}4 / 6 \\
67 \%\end{array}$ & $\begin{array}{r}4 / 4 \\
100 \% \\
\end{array}$ & $\begin{array}{l}1 / 6 \\
17 \%\end{array}$ & $\begin{array}{l}3 / 5 \\
60 \%\end{array}$ & $\begin{array}{l}3 / 6 \\
50 \%\end{array}$ & $\begin{array}{c}15 / 27 \\
56 \%\end{array}$ \\
\hline Total Seat Time & $1 \mathrm{~min}$ & 1 min & 1 min & $2 \mathrm{~min}$ & $2 \mathrm{~min}$ & $6 \mathrm{~min}$ \\
\hline Vocabulary. & $\underline{\text { View }}$ & $\underline{\text { View }}$ & $\underline{\text { View }}$ & View & $\underline{\text { View }}$ & \\
\hline Attempts & 1 of 3 & 1 of 3 & 1 of 3 & 1 of 3 & 2 of 3 & 6 \\
\hline Score & $\begin{array}{c}8 / 8 \\
100 \%\end{array}$ & $\begin{array}{c}8 / 8 \\
100 \%\end{array}$ & $\begin{array}{l}0 / 3 \\
0 \%\end{array}$ & $\begin{array}{l}5 / 8 \\
63 \%\end{array}$ & $\begin{array}{l}0 / 7 \\
0 \%\end{array}$ & $\begin{array}{c}21 / 34 \\
62 \%\end{array}$ \\
\hline Total Seat Time & $16 \mathrm{~min}$ & $2 \mathrm{~min}$ & $1 \mathrm{~min}$ & $1 \mathrm{~min}$ & $4 \mathrm{~min}$ & $23 \mathrm{~min}$ \\
\hline
\end{tabular}

A student does a various type of vocabulary and grammar exercises, with partial results that are summarized in total results for both items, which we use in graphic illustration, see Figure 1. Table 2 bellow depicts the results of online exercises, for example number 1 includes the exercise on multiple choice, 2 means matching exercises, 3 open questions exercises, 4 words orders and 5 find the mistake. As the results show, the participant reached the significantly low results in open questions exercises. The exercises aimed at searching mistakes were also low. The results of other types of exercises are similar. The highest score was reached in matching exercises.

Table 3: Grammar and Vocabulary Unit 2.

\begin{tabular}{|c|c|c|c|c|c|c|}
\hline & 01 & 02 & 03 & 04 & Review & Lesson Total \\
\hline$\underline{\text { Grammar }}$ & $\underline{\text { View }}$ & $\underline{\text { View }}$ & $\underline{\text { View }}$ & $\underline{\text { View }}$ & - & \\
\hline Attempts & 2 of 3 & 1 of 3 & 1 of 3 & 1 of 3 & 0 & 5 \\
\hline Score & $\begin{array}{l}3 / 4 \\
75 \%\end{array}$ & $\begin{array}{c}8 / 8 \\
100 \%\end{array}$ & $\begin{array}{l}3 / 6 \\
50 \%\end{array}$ & $\begin{array}{l}1 / 6 \\
17 \%\end{array}$ & - & $\begin{array}{c}15 / 24 \\
63 \%\end{array}$ \\
\hline Vocabulary. & $\underline{\text { View }}$ & $\underline{\text { View }}$ & - & $\underline{\text { View }}$ & $\underline{\text { View }}$ & \\
\hline Attempts & 1 of 3 & 1 of 3 & 0 & 1 of 3 & 1 of 3 & 4 \\
\hline Score & $\begin{array}{c}8 / 8 \\
100 \%\end{array}$ & $\begin{array}{l}6 / 8 \\
75 \%\end{array}$ & - & $\begin{array}{c}6 / 6 \\
100 \%\end{array}$ & $\begin{array}{l}4 / 6 \\
67 \%\end{array}$ & $\begin{array}{c}24 / 28 \\
86 \%\end{array}$ \\
\hline
\end{tabular}

A student continues to do a various type of vocabulary and grammar exercises, with partial results that are summarized in total results for both items, which we use in graphic illustration 
in comparison to the results from the Unit 1, see Figure 1. The results of both tables will be processed in the form of correlation graph, which shows dependence grammar on vocabulary.

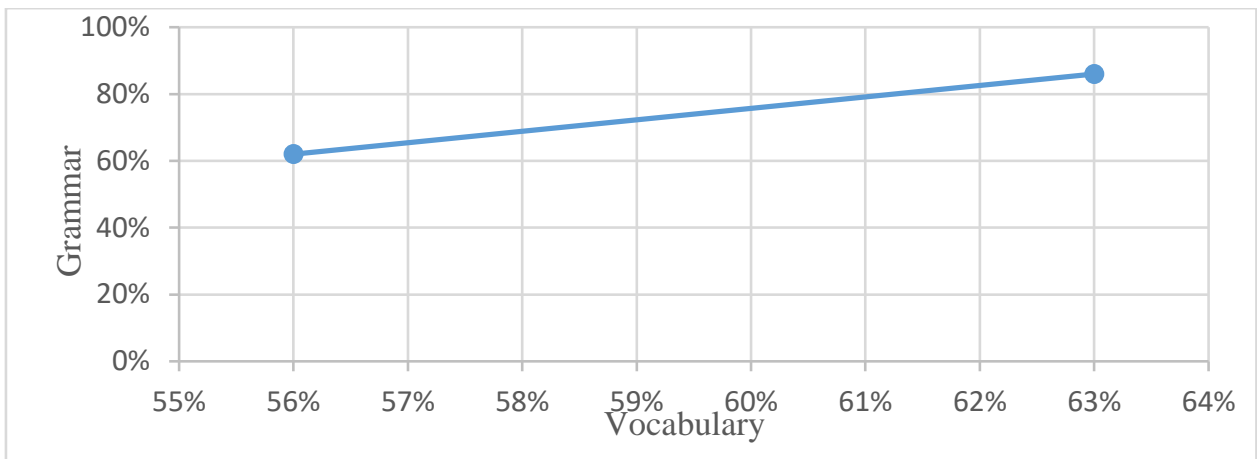

Fig. 1 Correlation between Vocabulary and Grammar.

As the graph depicts, there is a direct correlation between vocabulary and grammar. The improvement of vocabulary has a direct impact on improvement of grammar and vice versa.

\section{Conclusion}

The presented study considers the subject - Potentials of Information and communication technologies in foreign language teaching students suffering from High Functioning Autism. For the study, we have chosen one learner, diagnosed with Asperger syndrome because ASDs learners face more difficulties in foreign language learning in comparison to neurotypical population. The purpose of the research was to find out one of the way how to teach grammar and vocabulary of English as a foreign language ASDs students. As the responses on the grammar and vocabulary exercises indicate, open questions are the least suitable type of exercises for ASD students. Then exercises on finding mistakes are challenging for those type of learners. Under other conditions, matching exercises are the most suitable for ASD students because there a student reached $100 \%$ both grammar and vocabulary exercises. The possible solutions how to teach students having High functioning autism lies in the use of ICT.

\section{Acknowledgments}

This paper was financially supported by the Russian Foundation for Basic Research, grant No. 20-012-22046.

\section{References}

1. S. Baron-Cohen, Autism and Asperger syndrome, Oxford University Press (2008) Comorbid psychiatric disorders associated with Asperger syndrome/high-functioning autism: a community-and clinic-based study. Journal of autism and developmental disorders, 40(9), 1080-1093 (2010). URL: https://pubmed.ncbi.nlm.nih.gov/20177765/

2. M. Hutten, Highly Effective Research-Based Parenting Strategies for Children with Asperger's and High-Functioning Autism. Retrieved from: http://parentingautisticchild.com/public/pages/6f4fof82-e32a-48cd-a01da6890066c536.html 
3. E. Homolová, Výučba angličtiny žiakov so špecifickými vývinovými poruchami učenia a špeciálnymi výchovno-vzdelávacími potrebami. 2.čast' Výučba angličtiny žiakov s autizmom, Hradec Králové (2013)

4. C. Kendal, The Asperger's Syndrome Survival, Guide. What You and Your Family need Know, Solana Beach: Visions Publishing Inc (2009)

5. J. Kormos, A.M. Smith, Teaching Languages to Students with Specific Learning Differences, Center for Educational Policy Studies Journal, 2(3), 181-186 (2012)

6. I. Starcic, S. Bagon, ICT-supported learning for inclusion of people with special needs: Review of seven educational technology journals, 1970-2011, British Journal of Educational Technology, 45(2), 202-230 (2014)

7. P. Seidler, V. Kurincová, Špecifiká integrácie na vysokej škole, (2011). Retrieved from: http://www.grantjournal.com/issue/0102/PDF/0102belikova.pdf

8. M.L. Mattila, T. Hurtig, H. Haapsamo, K. Jussila, S. Kuusikko-Gauffin, M. Kielinen, D.L. Pauls, I. Moilanen J. Autism Dev Disord, 40(9):1080-93 (2010).

9. Z. Zelinková, Poruchy učení, Praha, Portál pp. 172-173 (2009)

10. O.Zelinková, Cizí jazyky a specifické poruchy učení, Havlíčkův Brod: Tobiáš (2005) 